\title{
Online teaching, student success, and retention in political science courses
}

\author{
Kerstin Hamann ${ }^{1} \cdot$ Rebecca A. Glazier ${ }^{2}$ - Bruce M. Wilson ${ }^{1} \cdot$ Philip H. Pollock ${ }^{1}$ \\ Published online: 30 July 2020 \\ (c) European Consortium for Political Research 2020
}

\begin{abstract}
The face of higher education is changing. One major trend is the fact that students are taking an increasing proportion of their courses online. That is, a growing number of students at not-for-profit private and public colleges and universities are taking some of their course work online and completing other parts in face-to-face courses. What impact does this mix of online and in-person course modalities have on student success? We answer this question by looking at political science majors at a large public university in the USA, taking into account demographics, achievement, and the mix of course modalities the students take $(n=1173)$. Through descriptive statistics, regression analysis, and predicted probabilities, we analyze how the mix of course modalities students enroll in impacts student success and retention. Results indicate that the success of all students declines as they take a greater proportion of their course load online. As universities seek to address this trend in higher education, they need to be particularly sensitive to ways to increase the success of online learners. Considering the needs of online learners is particularly relevant in the wake of the COVID-19 pandemic, which has prompted the shift to online education across the USA and elsewhere, a trend that is likely to continue in the future.
\end{abstract}

Keywords Education - Online learning - Online teaching · Student retention · Scholarship of teaching and learning

Kerstin Hamann

Kerstin.hamann@ucf.edu

Rebecca A. Glazier

raglazier@ualr.edu

Bruce M. Wilson

Bruce.Wilson@ucf.edu

Philip H. Pollock

Philip.pollock@ucf.edu

1 School of Politics, Security, and International Affairs, University of Central Florida, Orlando, FL 32816-1356, USA

2 School of Public Affairs, University of Arkansas at Little Rock, Little Rock, USA 


\section{Introduction}

Higher education in the USA, and elsewhere, is experiencing significant changes that challenge traditional approaches of teaching in college classrooms. These changes reflect growing diversity of the student body to include students from different racial and ethnic backgrounds, but also diversity in age, educational pathways, and academic preparedness, to cite just a few. Other changes include new pedagogies that explore active and problem-based learning, and, perhaps most significantly, instructional technology including courses delivered entirely online. ${ }^{1}$

Concurrently with these changes, colleges and universities are increasingly held accountable for student success. Legislators, trustees, college administrators, parents, prospective and current students, and others call attention to the importance of student success, often using retention and graduation rates as indicators (Polatajko and Monaghan 2017).

Here, we echo the concern for student success. We set out to understand better whether, and how, the significant changes in college education in the USA contribute to student success. We focus on what we consider the biggest innovation in higher education in recent decades, the spread of online course delivery, and specifically, whether and how the mix of online and face-to-face instruction affects student success in a large Political Science department. We use students majoring in Political Science and in International and Global Studies at the University of Central Florida, a large public university in the USA, as a case study. Our findings should concern educators and administrators alike: Students who take all their courses online are significantly less likely to be successful. This relationship persists despite demographic and academic controls. On the other hand, at a time when an increasing number of students are completing online courses, we find that taking one online course, or even a few online courses, as part of their course load has a minimal effect on their academic success. But those students who, for whatever reasons, need or want to take all of their courses online are significantly less likely to be successful. This finding indicates a need to think about student advising as well as effective online pedagogies.

\section{Online courses and student success}

In the early years of online education, students enrolled in online courses constituted a distinct educational population. They were often enrolled exclusively in online courses, were older than the traditional student population (Diaz 2002; Dutton et al. 2002), and were more likely to be working full-time jobs (Perna 2010). Although some differences between entirely online and entirely face-to-face students persist today (Kena et al. 2015), a strict division of the student body into online-only and face-to-face-only categories no longer holds for a large segment of students.

\footnotetext{
1 We use the term "course" to denote semester-long instructional units (e.g. Comparative Politics, International Relations Theory, American National Government, Political Theory, etc.).
} 
More students than ever are including both modalities into their course load (Jaggars 2014; Murphy and Stewart 2017). As universities in the USA have moved away from a strictly in-person instructional model, students' learning environment has fundamentally changed, leading more students to take a mix of online and face-toface courses.

The data indicate that this shift is foundational. A growing number of students, including both traditional and nontraditional college students, are taking online courses (Ortagus 2017; Seaman et al. 2018). According to Seaman et al. (2018: 3 ), during the fall 2016 semester, the number of students enrolling in one or more online courses was in excess of 6.3 million, or almost one-third $(31.6 \%)$ of all students. Of those, almost half (14.9\%) enrolled exclusively in distance courses; the remainder $(16.7 \%)$ combined distance and face-to-face course modalities. That is, $52.8 \%$ of all students who took at least one distance course also took an on-campus course. These data suggest that online coursework is now part of the mainstream of higher education. Furthermore, online education is no longer the domain of forprofit institutions. The vast majority $(69.1 \%)$ of public university administrators see online course offerings as important to the future of their institutions (Allen and Seaman 2013: 4), and over two-thirds (68.9\%) of all students taking at least one online course are doing so at a public college or university (Seaman et al. 2018: 13).

Thus, as online courses become a more common part of the educational experience for a growing number of college students, the distinctions between online students and face-to-face students become less clear. Rather than being the pedagogy of choice for specific student demographics, online courses are increasingly more of a norm and less of an exception for the general student population. This is perhaps even more the case in the wake of COVID-19, when most colleges and universities in the USA and elsewhere quickly converted face-to-face instruction to remote pedagogies and even students in primary and secondary schools have switched to remote instruction.

This new learning environment leads us as researchers to ask questions about whether the proportion of online courses students take affects their overall success. Concerns about the comparative completion rates of online versus face-to-face students have been raised by instructors and researchers across disciplines (e.g., Jenkins 2012). Whereas much of the previous literature has directly compared success rates in face-to-face only versus online only courses, we take individual students as the unit of analysis here and look at how the proportion of their course load that is online might impact their overall success.

What do we expect to find? Early concerns about online teaching and student learning centered on the issue of efficacy of the new modality as compared to traditional face-to-face teaching environments. Many meta-studies and assessments of individual courses, including political science courses, show that students demonstrate very similar learning outcomes in online and face-to-face modalities. That is, there is no significant difference in student learning outcomes across modalities (e.g. Lim et al. 2007; Means et al. 2010; Neuhauser 2010; Ni 2013; Stack 2015). Other studies (e.g. Nguyen 2015: 309) conclude that there is "robust evidence to suggest online learning is generally at least as effective as the traditional format." Those results are recently confirmed by Soffer and Nachmias (2018: 541), who posit that 
"online courses are as effective as or more effective than F2F courses." Thus, the studies suggest that those students who complete a course online generally are on par with students completing a course in the face-to-face modality, when considering learning outcomes.

At the same time, other studies comparing online and face-to-face courses indicate that success in online courses is more difficult than in face-to-face settings. The same course taught online tends to have lower retention rates than its face-toface corollary (Glazier 2016; Murphy and Stewart 2017; Smart and Saxon 2016; Wladis et al. 2014), even when it is taught by the same professor (Hart et al. 2018), and even when the exact same lectures are used (Roberts 2015). Student success, whether measured by persistence, learning, or graduation, is often lower in online courses (Dziuban et al. 2006; Hart et al. 2018; Johnson and Mejia 2014; McLaren 2004; Moskal and Dziuban 2001; Patterson and McFadden 2009; Stover 2005; Urtel 2008; Xu and Jaggars 2014). This literature leads us to expect lower retention rates as students take a higher proportion of courses online. But is there a tipping point? Is taking one online course fundamentally different from taking a fully online load?

Research that connects the proportion of online courses in a student's course load to student success is scarce. However, one area of research that might be able to inform our expectations about online course load proportions in our analysis is hybrid courses, sometimes also referred to as "blended" or "mixed-mode" courses. We know that the categorical distinction between students who are exclusively online or exclusively face-to-face is fading in importance. Just as a college student's overall course load today might be made up of some online and some face-to-face courses, in a hybrid course, some face-to-face instruction is replaced by online instruction so that the learning environment includes some online and some face-toface elements. Hybrid courses are growing in popularity, with $79 \%$ of public institutions of higher education in the USA offering such courses (McGee and Reis 2012: 7).

What does this mean for student success? The literature on hybrid courses indicates that they have the potential to bring the best of both modalities together (Vaughan 2010; Verhoeven and Rudchenko 2013). As Garrison and Vaughan (2013: 24) put it, in hybrid courses, "the face-to-face and online means of communication are fused in a way that capitalizes on the strengths of each." This may mean that students who take a mix of course modalities may be able to benefit from the particular advantage of each of these modalities.

However, although some research indicates that interest and learning may be higher in hybrid courses (Bolsen et al. 2016; Denhart 2010; Nowell 2011), the overwhelming evidence indicates that completion rates are lower. Radunovich and Acharya (2018) conclude that students are less likely to engage with the online material in a hybrid course, and Sewell (2016) finds that withdrawal rates for both hybrid and online courses are higher than for the same courses taught through a face-to-face mode. In fact, even when only a small portion of a hybrid course takes place online, student completion rates decline (Murphy and Stewart 2017). Here again, we see that when the online modality is brought into the equation, the downside is not student learning, but student retention. Baudewyns et al. (2018) look specifically at the uphill battle that MOOCs (Massive Online Only Courses) face in terms of retention, 
where course attrition can be as high as $85-90 \%$. While MOOCs are in many ways different from online courses that are offered as part of a regular degree program for degree-seeking students enrolled in an institution of higher learning, the study still suggests that perhaps there is something about the online environment that makes retention more difficult, especially as the distance from the instructor increases with class size.

Thus, these findings regarding student success rates in online, hybrid, and faceto-face courses lead us to expect that student retention will be lower as the proportion of their course load that is taken online increases. Although hybrid courses may be preferred to online (Denhart 2010), and the equivalent assumption that some face-to-face courses may be preferred to all online courses, it appears that the faceto-face instructional environment, where students see and connect directly with their instructor, makes retaining students easier, even if this direct connection occurs more sporadically compared to a fully face-to-face course.

At the same time, the student population is increasingly heterogenous as students vary in age, gender, race and ethnic background, and academic preparedness. It may also be the case that particular student demographics may respond differently to taking a greater proportion of their course load online. Various student demographics such as age, gender, rank, and academic readiness impact online course completion (Aragon and Johnson 2008; Hare 2013; Hart et al. 2018; McLaren 2004; Twigg 2009; Urtel 2008). Research by Glazier et al. (2020) specifically indicates that age and gender may be important factors that condition the effects of the proportion of courses that are taken online. Other research by Glazier et al. (2019) indicates that transfer status may also impact these effects. Additional factors that possibly impact student retention and success may include students' socioeconomic background, where those students who take a larger share of courses online may have additional responsibilities (e.g. full-time employment, family) and fewer resources than students who select the majority, or all, their courses in person. Thus, we expect that the effect of the share of online courses on overall student success varies across different student demographics.

\section{The study}

We look at how the online proportion of a student's course load impacts their overall success by using data from a large university in the USA. The key dependent variable we use to measure success is whether the student is retained (either re-enrolled or graduated). Retention is a key metric of success used by policymakers and universities in performance-based funding models (Polatajko and Monaghan, 2017). The University of Central Florida is a large, public university that has offered online education as part of its regular curriculum for over two decades. Faculty members are required to successfully complete a one-semester training course prior to being 
able to teach a course that is delivered fully online; ${ }^{2}$ the university offers extensive technical support for both students and faculty; and faculty are supported by instructional designers when designing and delivering their online courses. The university has received national awards and accolades for its online education; it also ranks highly among US universities regarding number of students enrolling in online courses (Seaman et al. 2018: 31). Our study focuses on the success of students enrolled in a major housed in the Political Science department, which offers undergraduate degrees in Political Science and in International and Global Studies. The approximately 1300 majors can choose to complete their degrees by enrolling in face-to-face courses, online courses, or a mix of both. Mirroring the university's recognized high quality in online education, the department's online degree in Political Science has also been ranked highest in the country by some college ranking organizations.

\section{Data and analysis: online learning and academic success}

Our data are based on course performance and demographic attributes for all UCF students majoring in either Political Science or International and Global Studies. The data provide information on all career credit hours attempted as of Fall 2016. Credit hours are categorized as "live" or "online" and are further measured as "successful" (a grade of A, B, or C) or "unsuccessful” (D, F, I, N, or W). ${ }^{3}$ Students' transfer status (transfer or nontransfer), GPA (as of Fall 2016), and re-enrollment status in Fall 2017 (graduated/re-enrolled versus not re-enrolled) are measured as well. Finally, the dataset includes key demographics—age, gender, and race. ${ }^{4}$

Overall, how does the live-online modality mix relate to student success? To get a preliminary idea, we first created a five-category ordinal variable, dividing students into categories based upon the percentage of their course load that was online. Students who take no online courses anchor one end of the spectrum, and completely online students anchor the other. The students in the middle are not evenly distributed, so we divided them into three approximately equal categories: those taking between 1 and $28 \%$ of their hours online, those taking more than 28 but less than $50 \%$ of their hours online, and those taking more than $50 \%$ but less than $100 \%$ of their hours online. Table 1 compares these five groups of students on several academic metrics: GPA (Fall 2016), percentage successful hours,

\footnotetext{
${ }^{2}$ Instructors also have to complete a one-semester training course before they are qualified to teach a hybrid (mixed-method) course at the University of Central Florida.

3 These grade designations for "successful" or "unsuccessful" course completion are commonly used in higher education (see Moskal and Dziuban 2001). The authors wish to thank Carlos E. Piemonti, MBA, UCF Institutional Knowledge Management, for providing the original dataset.

${ }^{4}$ While we acknowledge the potential effect of socioeconomic factors, we do not have access to student data regarding their socioeconomic background. Overall, 22 per cent of the University of Central Florida's students are first-generation students. The University of Central Florida also enrolls a large number of students from underrepresented groups (47.8\% belonged to a minority group in fall 2019); the university is designated by the US Department of Education as a Hispanic Serving Institution where more than $25 \%$ of the total student body is of Hispanic background.
} 
Table 1 Academic Metrics, by Percentage of Hours Online

\begin{tabular}{lllll}
\hline Percent Hours Online & GPA, Fall 2016 & $\begin{array}{l}\text { Percent Pass, } \\
\text { All hours }\end{array}$ & $\begin{array}{l}\text { Percentage } \\
\text { Transfers }\end{array}$ & $\begin{array}{l}\text { Percentage Re- } \\
\text { enrolled, Fall } \\
2017^{\mathrm{a}}\end{array}$ \\
\hline 0\% & 3.10 & 86.28 & 36.39 & 92.13 \\
GT 0 LE 28 & 3.20 & 88.24 & 43.22 & 94.07 \\
GT 28 LT 50 & 3.06 & 84.09 & 47.32 & 90.18 \\
GE 50 LT 100 & 3.05 & 81.47 & 61.60 & 90.72 \\
100\% & 2.97 & 77.50 & 85.96 & 74.85 \\
Total & 3.08 & 84.00 & 52.17 & 89.34 \\
\hline
\end{tabular}

Number of cases: 0\% online, 305; GT 0 LE 28\%, 236; GT 28 LT 50\%, 224; GE 50 LT 100\%, 237; 100\%, 171. Total, 1173

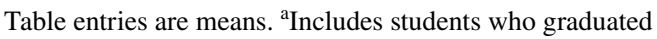

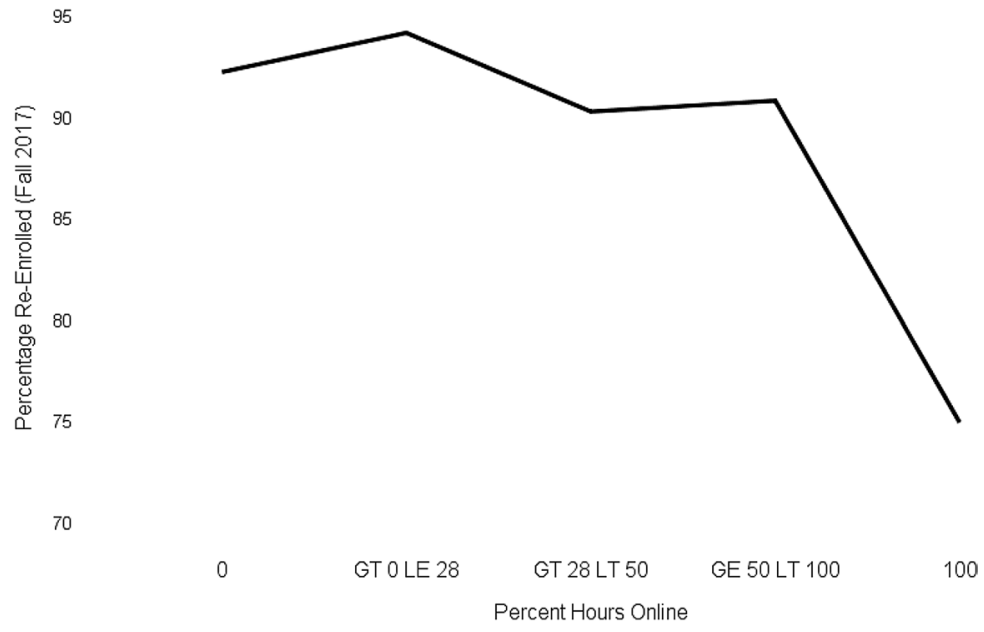

Fig. 1 Percentage Re-enrolled or Graduated (Fall 2017), by Percentage of Hours Online

percentage transfer students, and, most critically, percentage who re-enrolled (or graduated) in Fall 2017.

Even a cursory examination of these data leads to one takeaway: Students whose course loads are exclusively online inhabit a world that is distinctly less successful than the world inhabited by all other students, regardless of modality mix. Whereas each student group having at least some live hours shows little differentiation, the "100 percenters" stand alone: the lowest beginning GPA (2.97), the fewest successful hours $(77.5 \%)$, and by far the worst re-enrollment rate $(74.85 \%)$. Figure 1, based on the re-enrollment numbers in Table 1, provides a visual signature. We expected that student success might decline as the proportion of online courses in their overall course load increased, but we see only a slight trend in that direction. What Fig. 1 instead dramatically illustrates is the 
difference between the fully online students in our sample and the rest of the population.

Might these disappointing numbers be spurious artifacts of demographic factors, such as age, race, or gender? Does transfer status- $86 \%$ of the 100 percenters are transfer students-confound the results? Table 2 provides some clues. Model 1 is merely a logit version of Table 1's re-enrollment column, and it confirms that students taking at least some live hours with their online courses are as likely to reenroll as are students taking zero online hours. Now track the odds ratio on the $100 \%$ row as we add GPA and transfer status (Model 2) and race, gender, and age (Model 3 ). In Model 1, exclusively online students are $75 \%$ less likely than " 0 percenters" to re-enroll, a likelihood that barely improves with statistical control: $65 \%$ less likely in Model 2 (controlling for GPA and transfer status), and 66\% in the full model (Model 3).

\section{Discussion and conclusion}

Students are embracing online courses for a variety of reasons-be it convenience, learning style, or other reasons. At the same time, our data and findings suggest that students whose course load is entirely online are significantly less likely to be successful than those students who also, or exclusively, attend face-to-face courses, as measured in retention rates (re-enrollment in the next semester or graduation). Notably, these findings hold regardless of characteristics commonly used to distinguish different student demographics-gender, race and ethnicity, and age. Some existing literature on student success in courses instructed in various modalities points to potential advantages of face-to-face instruction, which mirrors our findings here. At the same time, our results contrast with earlier findings that indicate differentiated effects of the online course load on student success as measured in grades based on student key demographics (Glazier et al. 2019). When looking at retention rates, all student groups are less likely to re-enroll in a future term if they take all their courses online. These mixed findings indicate the need for additional research that helps us understand the conditioning factors on student success in different environments and for different demographic groups.

Thus, future research will need to look more into why this is the case. ${ }^{5}$ Here, we can offer some initial hypotheses. We have no systematic data about the student population in this study that would tell us why students are opting to take all their courses online. Perhaps they have additional obligations, such as working more hours, family obligations, or other time commitments that makes an all online course load a desirable option. Earlier studies suggest, for example, that online students tend to be slightly older, which may come with additional responsibilities. Perhaps they live further away, do not want to or cannot relocate to live closer to the university, and the commute to campus is not practical. While we do not have those data

\footnotetext{
5 For an overview of the literature evaluating online teaching and learning in political science and international relations, see Hamann et al. (2017).
} 


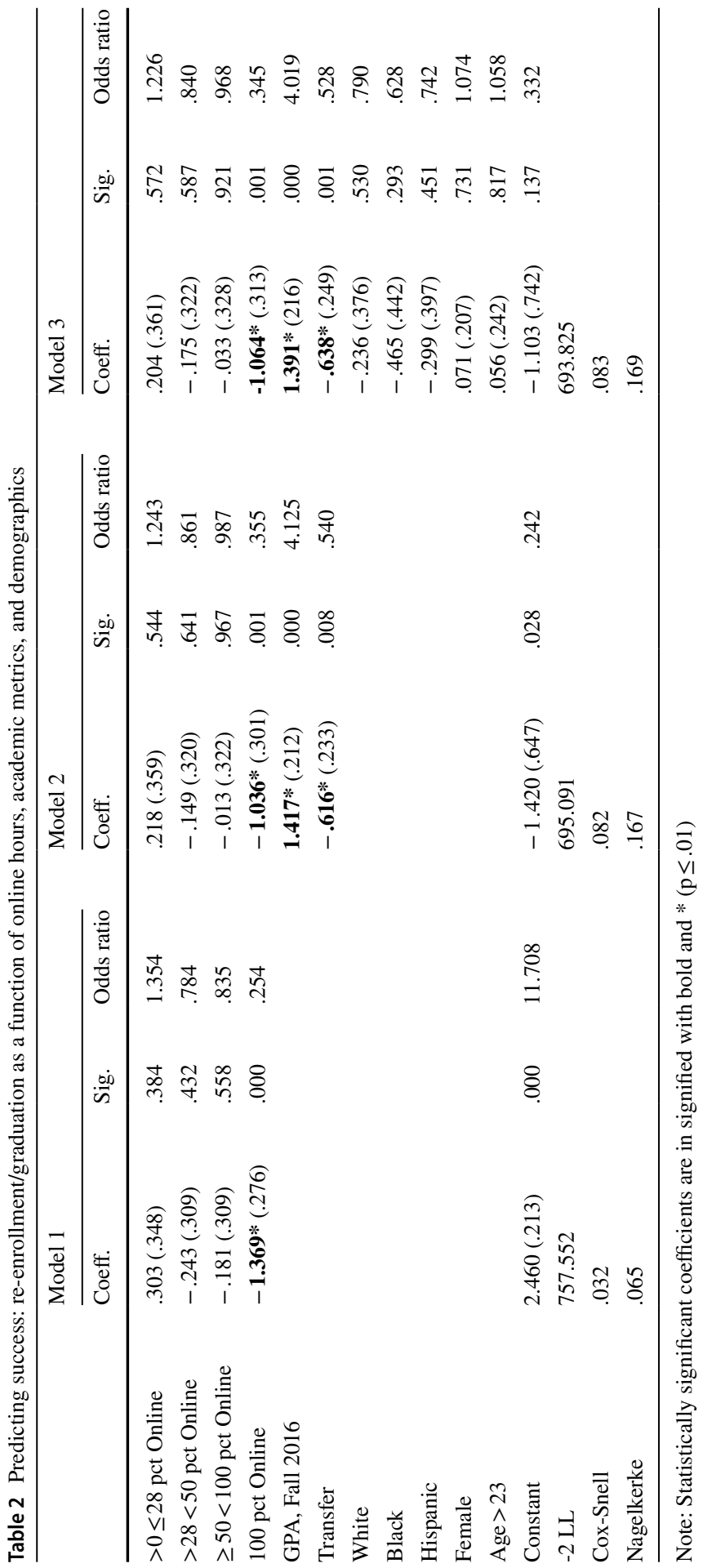


for the specific students in our study, we know that over one-third of all students that take all their course online in the state where the University of Central Florida is located live outside of the state. That is, there may be important additional student demographics that we are unable to explore systematically due to a lack of data.

Similarly, we do not know why students are less likely to be retained if they take all their courses online, especially when a good portion of the research cited above indicates that students learn about as much in online courses as they do in faceto-face courses, including in political science, and that online instruction can offer engagement opportunities that students value (see Hamann et al. 2012). Again, in the absence of existing data, we can only venture some hypotheses. It may be that the online student population is less motivated to re-enroll because they lack the direct, personal connection to their professor. Or perhaps they find it more difficult to connect with student support services, such as financial aid, academic advisors, or counseling services, and miss out on engagement opportunities, such as student groups and organizations, speakers and events on campus, etc., that makes them feel less connected and motivated to return in a future semester. Willging and Johnson's (2009) study on dropout rates from an online graduate program identifies varied and individually unique reasons rather than demographic patterns or technology issues that account for students' dropout rate. While this may be different for undergraduate students, it nonetheless suggests that there are no clear patterns that explain why students are less likely to be retained when they complete all coursework online.

While we do not have the answers to these questions, we can still learn from our findings. For example, students might be well advised not to take all their courses online, although this might not be practical for all our students, especially those living further away or with responsibilities that would make it prohibitive to earn a degree while attending courses on campus. At the same time, as students are increasingly completing at least part, or even all, of their college degrees online, it is important that colleges are aware of the retention gap between all online students and those taking all, or many, of their courses in the brick-and-mortar classroom so they can devise strategies that address the needs of online learners. Following the complete shift to online instruction across the USA in response to the COVID-19 pandemic, it is possible that a growing number of institutions and students will take more online instruction in future semesters. This makes it all the more pertinent that future studies explore the determinants of student success in online classes including student mastery of course contents and grades but also student retention.

\section{References}

Allen, I. E. and Seaman, J. 2013. Changing Course: Ten Years of Tracking Online Education in the United States. Babson Survey Research Group.

Aragon, S.R., and E.S. Johnson. 2008. Factors influencing completion and noncompletion of community college online courses. The American Journal of Distance Education 22(3): 146-158.

Bolsen, T., M. Evans, and A. McCaghren Fleming. 2016. A comparison of online and face-to-face approaches to teaching Introduction to American Government. Journal of Political Science Education 12(3): 302-317. 
Baudewyns, P., M. Cogels, S. Dandache, E. Hamonic, V. Legrand, M. Reuchamps, and N. SchiffinoLeclercq. 2018. Teaching political science with a MOOC: Analysing the supply side and the demand side. European Political Science 17(2): 276-295.

Denhart, R. 2010. Non-traditional undergraduate perceptions of the effectiveness of hybrid. Journal Of Innovative Education 8(2): 313-346.

Diaz, D. P. 2002. Online Drop Rate Revisited. Extending the Pedagogy of Threaded-Topic Discussions. 2002(1).

Dutton, J., M. Dutton, and J. Perry. 2002. How do online students differ from lecture students? Journal of Asynchronous Learning Networks 6(1): 1-20.

Dziuban, C., J. Hartman, F. Juge, P. Moskal, and S. Sorg. 2006. Blended Learning Enters the Mainstream. In The Handbook of Blended Learning: Global Perspectives, ed. C.J. Bonk and C.R. Graham, 195-206. Local Designs, San Francisco: Pfeiffer.

Garrison, D.R., and N.D. Vaughan. 2013. Institutional change and leadership associated with blended learning innovation: Two case studies. The Internet and Higher Education 18: 24-28.

Glazier, R.A. 2016. Building rapport to improve retention and success in online classes. Journal of Political Science Education 12(4): 437-456.

Glazier, R.A., K. Hamann, P.H. Pollock, and B.M. Wilson. 2020. Age, gender, and student success: Mixing face-to-face and online courses in Political Science. Journal of Political Science Education 16(2): 142-157.

Glazier, R. A., Hamann, K., Pollock, P. H. and Wilson, B. M. 2019. What drives student success? Assessing the combined effect of transfer students and online courses. Teaching in Higher Education. Published Online First, November 4, 2019. https://doi.org/10.1080/13562517.2019.1686701.

Hamann, K., P.H. Pollock, G. Smith, and B.M. Wilson. 2017. What do we know about teaching and learning in political science in the digital era? Politics 37(2): 229-238.

Hamann, K., P.H. Pollock, and B.M. Wilson. 2012. Assessing student perceptions of the benefits of discussions in small-group, large-class, and online learning contexts. College Teaching 60(2): 65-75.

Hare, B.K. 2013. Classroom interventions to reduce failure \& withdrawal in CS1: A field report. Journal of Computing Sciences in Colleges 28(5): 228-235.

Hart, C., E. Friedmann, and M. Hill. 2018. Online course-taking and student outcomes in California community colleges'. Education Finance and Policy 13(1): 42-71.

Jaggars, S.Smith. 2014. Choosing between online and face-to-face courses: Community college student voices. American Journal of Distance Education 28(1): 27-38.

Jenkins, R. 2012. Online classes and college completion. The Chronicle of Higher Education 58: 26.

Johnson, H.P., and M.C. Mejia. 2014. Online Learning and Student Outcomes in California's Community Colleges. San Francisco: Public Policy Institute of California.

Kena, G., L. Musu-Gillette, J. Robinson, X. Wang, A. Rathbun, J. Zhang, S. Wilkinson-Flicker, A. Barmer, and V.V. Dunlop. 2015. The Condition of Education 2015, 2015-2144. Washington, DC: US Department of Education, NCES.

Lim, D. H., Morris, M. L. and Kupritz, V. W. 2007. Online vs. blended learning: Differences in instructional outcomes and learner satisfaction. Journal of Asynchronous Learning Networks 11(2): $27-42$.

McGee, P., and A. Reis. 2012. Blended course design: A synthesis of best practices. Journal of Asynchronous Learning Networks 16(4): 7-22.

McLaren, C.H. 2004. A comparison of student persistence and performance in online and classroom business statistics experiences. Decision Sciences Journal of Innovative Education 2(1): 1-10.

Means, B., Y. Toyama, R. Murphy, M. Bakia, and K. Jones. 2010. Evaluation of Evidence Based Practices in Online Learning: A Meta Analysis and Review of Online Learning Studies. Washington, D.C: U.S. Department of Education.

Moskal, P.D., and C.D. Dziuban. 2001. Present and Future Directions for Assessing Cybereducation: The Changing Research Paradigm. In Cybereducation: The Future of Long-Distance Learning, ed. L.R. Vandervert, L.V. Shavinina, and R.A. Cornell, 157-184. New York: Mary Ann Liebert.

Murphy, C.A., and J.C. Stewart. 2017. On-campus students taking online courses: Factors associated with unsuccessful course completion. The Internet and Higher Education 34: 1-9.

Nguyen, T. 2015. The effectiveness of online learning: Beyond no significant difference and future horizons. MERLOT Journal of Online Learning and Teaching 11(2): 309-310.

Ni, A.Y. 2013. Comparing the effectiveness of classroom and online learning: Teaching research methods. Journal of Public Affairs Education 19(2): 199-215.

Nowell, G. 2011. Student course evaluations in traditional and blended courses: A case study. American Journal of Business Education 4(1): 13-18. 
Neuhauser, C. 2010. Learning style and effectiveness of online and face-to-face instruction. The American Journal of Distance Education 16(2): 99-113.

Ortagus, J.C. 2017. From the periphery to prominence: An examination of the changing profile of online students in American higher education. The Internet and Higher Education 32: 47-57.

Patterson, B. and McFadden, C. 2009. Attrition in online and campus degree programs. Online Journal of Distance Learning Administration 12(2).

Perna, L.W. 2010. Understanding the working college student. Academe 96(4): 30-33.

Polatajko, M.M. and Monaghan, C.H. 2017.'Performance Funding of United States' Public Higher Education: Impact on Graduation and Retention Rates', in S. Mukerji and P. Tripathi (eds.) Handbook of Research on Administration, Policy, and Leadership in Higher Education, Hershey, PA: IGI Global, pp. 496-517.

Radunovich, H.L., and Acharya, S. 2018. If you flip it, will they watch? Case evaluation of a hybrid course. NACTA Journal 62(1).

Roberts, J.C. 2015. Evaluating the effectiveness of lecture capture: Lessons learned from an undergraduate political research class. Journal of Political Science Education 11(1): 45-60.

Seaman, J. E, Allen, I. E. and Seaman, J. 2018. Grade Increase: Tracking Distance Education in the United States, Babson Research Group. http://www.onlinelearningsurvey.com/highered.html.

Sewell, T. R. 2016. Student Outcomes in Traditional, Tybrid, and Online Courses in Community College Career and Technical Education Programs. Ed.D., Educational Leadership, East Tennessee State University.

Smart, B.M., and D.P. Saxon. 2016. Online versus traditional classroom instruction: An examination of developmental English courses at an Alabama community college. Community College Journal of Research and Practice 40(5): 394-400. https://doi.org/10.1080/10668926.2015.1065777.

Soffer, T., and R. Nachmias. 2018. Effectiveness of learning in online academic courses compared with face-to-face courses in higher education. Journal of Computer Assisted learning 34: 534-543. https ://doi.org/10.1111/jcal.12258.

Stack, S. 2015. Learning outcomes in an online vs traditional course. International Journal for the Scholarship of Teaching and Learning 9(1), Article 5. https://doi.org/10.20429/ijsotl.2015.090105.

Stover, C. 2005. Measuring-and understanding-student retention. Distance Education Report 9(16): 1-7.

Twigg, C.A. 2009. Using asynchronous learning in redesign: Reaching and retaining the at-risk student. Journal of Asynchronous Learning Networks 13(3): 147-155.

Urtel, M.G. 2008. Assessing academic performance between traditional and distance education course formats. Journal of Educational Technology \& Society 11(1): 322-330.

Vaughan, N.D. 2010. A blended community of inquiry approach: Linking student engagement and course redesign. The Internet and Higher Education 13(1-2): 60-65.

Verhoeven, P., and T. Rudchenko. 2013. Student performance in a principle of microeconomics course under hybrid and face-to-face delivery. American Journal of Educational Research 1(10): 413-418.

Willging, P.A., and S.D. Johnson. 2009. Factors that influence students' decision to dropout of online courses. Journal of Asynchronous Learning Networks 13(3): 115-127.

Wladis, C., K. Wladis, and A.C. Hachey. 2014. The role of enrollment choice in online education: Course selection rationale and course difficulty as factors affecting retention. Online Learning 18(3): n3.

Xu, D., and S.S. Jaggars. 2014. Performance gaps between online and face-to-face courses: Differences across types of students and academic subject areas. The Journal of Higher Education 85(5): 633-659.

Publisher's Note Springer Nature remains neutral with regard to jurisdictional claims in published maps and institutional affiliations.

Kerstin Hamann is Pegasus Professor in the School of Politics, Security, and International Affairs at the University of Central Florida. Her research interests are in West European politics with a focus on the role of organized labor and Spanish politics, and the Scholarship of Teaching and Learning. She has published numerous books, book chapters, and articles in journals such as Teaching in Higher Education, Journal of Political Science Education, Politics, Comparative Political Studies, Comparative Politics, West European Politics, Party Politics, British Journal of Industrial Relations, European Journal of Industrial Relations, and College Teaching, among others. 
Rebecca A. Glazier is an Associate Professor of political science in the School of Public Affairs at the University of Arkansas at Little Rock. She studies the scholarship of teaching and learning, in addition to research on religion and politics, political communication, and US foreign policy.

Bruce M. Wilson is Professor in the School of Politics, Security, and International Affairs at the University of Central Florida and Associated Senior Researcher at the Chr. Michelsen Institute, Bergen. His research on the Scholarship of Teaching and Learning has appeared in journals such as the Journal of Political Science Education, College Teaching, and Teaching in Higher Education. He is currently project leader for "Elevating Water Rights to Human Rights" (Norwegian Research Council). His research on comparative judicial politics has appeared in Comparative Political Studies, Water, Journal of Latin American Studies, Health and Human Rights, Latin American Politics and Society, among others.

Philip H. Pollock is a retired Professor of political science at the University of Central Florida, where he taught courses in American politics and data analysis. Recent research interests include the Scholarship of Teaching and Learning, which has been published in PS, the Journal of Political Science Education, and other venues. The sixth edition of Pollock's data analysis textbook, The Essentials of Political Analysis (CQ Press), co-authored with Barry C. Edwards, was released in 2019. 